\title{
Symbol kalicha ve veřejném prostoru utrakvistických měst
}

\author{
Kateřina HorníČKOVÁ
}

Základní význam obrazu kalicha je v českém utrakvismu 15. a 16. století postulován z hlediska teologického jako symbolický odkaz na přijímání pod obojí. ${ }^{1}$ Přestože eucharistický rozměr symbolu, který je úzce vázán na náboženskou praxi, zůstane jeho hlavní významovou rovinou po celou existenci utrakvismu, se vznikem kališnických elit $\mathrm{v}$ polovině 15 . století nabírá na důležitosti i jeho funkce reprezentační a sebeidentifikační, vymezující převahu utrakvismu v prostředí dané městské komunity. $S$ etablováním se utrakvismu v prostředí především královských měst se motivy symbolické komunikace v urbánním prostoru rozšírí o tento náboženský symbol.

Pomocí symbolické obrazové komunikace ${ }^{2}$ se městské komunity a jejich elity politicky a nábožensky prezentovaly, identifiko-

\footnotetext{
Tento článek se nezabývá kalichem jako atributem Jana Husa. O symbolice kalicha Milena BARTLOVÁ, Ikonografie kalicha, symbolu busitství, in: Jan Hus na přelomu tisíciletí, edd. Miloš Drda - František J. Holeček - Zdeněk Vybíral, Tábor 2001 (= Husitský Tábor. Supplementum 1), s. 453-487.

${ }^{2}$ Prostor je zde chápán jak prostor fyzický, tak vymezený sociokulturně či mocensky. K proměnám koncepce veřejného prostoru Susanne RaU - Gerd
} 
valy se v rámci zemského stavovského uspořádání a pomocí symboliky vyjadřovaly i vnější, např. vrchnostenské, a vnitřní korporátní vazby. Symbolická komunikace směřovala i dovnitř města, kde sloužila $\mathrm{k}$ vyjádření jednoty jeho obyvatel a vnitřních společenských vazeb městských komunit. Nápisy a vyobrazení na městských stavbách, fortifikacích, domech, kostelích, jejich vnitřním vybavení a např. v chorálních knihách se staly prostředkem vyjádření vlastního sebeurčení a - často spíše imaginární a idealizované - převahy městské komunity či jejích složek. Funkce veřejných obrazů jako prostředku reprezentace a sebeidentifikace městských komunit nevylučuje další funkce těchto obrazů a symbolů, např. estetickou či memoriální, které patří $\mathrm{k}$ tradičním hodnotám města chápaného dobově a $z$ hlediska přediva společenských vztahů jako commune. ${ }^{3} \mathrm{~A}$ přes značné ztráty $\mathrm{v}$ této oblasti veřejných a poloveřejných obrazư ${ }^{4}$ je to právě městské prostředí, kde se zobrazení kalicha v těchto funkcích nejčastěji objevuje jako přihlášení se komunity $\mathrm{k}$ utrakvismu jak v rovině náboženské a kultovní, tak postupně i v rovině politické.

SCHWERHOFF, Öffentliche Räume in der Früben Neuzeit. Überlegungen zu Leitbegriffen und Themen eines Forschungsfeldes, in: Zwischen Gotteshaus und Taverne. Öffentliche Räume in Spätmittelalter und Früher Neuzeit, edd. Susanne Rau - Gerd Schwerhoff, Köln 2004, s. 11-52, zde s. 22-23.

${ }^{3}$ Elisabeth Gruber, City as Commune, in: Meanings of Community across Medieval Eurasia, edd. Eirik Hovden - Christina Lutter - Walter Pohl, Leiden 2016, s. 97-124, zde s. 104-105.

${ }^{4}$ Srov. patent místodržícího Karla $z$ Lichtenštejna o zamalování veřejných obrazů škodlivých katolickému náboženství, 1624, viz Jan František BECKOVSKÝ, Poselkyně starých príbébi̊v českých II (1526-1715), ed. Antonín REZEK, sv. 2 (1608-1624), Praha 1879, s. 402-403. Srov. Michal ŠrONĚK, Jan Beckovský, protireformační ikonoklasmus a husitské obrazy, Acta Universitatis Carolinae - Historia Universitatis Carolinae Pragensis 47, 2007, č. 1-2, s. 193-196. Naposled se ztrátami materiálu v důsledku protireformace zabýval Michal Š́nONĚK, De sacris imaginibus. Patroni, malíri a obrazy predhusitské Praby, Praha 2013 (= Opera minora historiae artium 5), s. 57-70.
Jedním z raných přikladů takového využití je nedochované vyobrazení anděla $s$ kalichem na štítu umístěném na vnější táborské bráně, popsané Eneou Silviem Piccolominim v dopise kardinálu Carvajalovi po jeho cestě na sněm do Benešova v roce $1451 .{ }^{5}$ Poměrně tradiční ikonografie anděla ${ }^{6} s$ kalichem na bráně je autorem dopisu chápána jako didaktická připomínka husitského přijímání pod obojí, která má skrze obraz vést lid $\mathrm{k}$ praxi sub utraque. Enea Silvio tak interpretuje vyobrazení ve smyslu eucharistické náboženské praxe, která byla sama o sobě identifikačním znakem táborské komunity, husitství a později celé české reformace. Už jeho interpretace nicméně naznačuje, že obraz lze nahlížet i v širším kontextu: umístění na bráně ve vstupu do města umocňuje totiž poselství obrazu jako veřejného a proklamativního sebevyjádření utrakvistického města směrem $\mathrm{k}$ příchozím.

Dle popisu Eney Silvia byl štít s obrazem anděla s kalichem na průčelí brány kombinován s obrazem slepého vojevůdce Tábora Jana Žižky. Spojení s obrazem Žižky a s minulostí města podporuje sebeidentifikační funkci kalicha, reprezentační funkci zase umístění obrazu na bráně, tedy na místě, kde se v českém prostře-

${ }^{5}$ „Na vnější bráně města byly dva štíty; na jednom byl obraz anděla, jak drží kalich, jako by radil lidu, aby prijímal pod způsobou vína, na druhém byl vymalován Žižka, stařec slepý na obě oči. Tento byl kdysi vojevůdcem Táborů... Jím prý byli věrní křestané často poraženi... Ale tohoto ctí táboři jako božstvo, a ačkoli proklínají všechny obrazy, přec uctívají obraz tohoto muže a prokazují Žižkovi čest, kterou Kristu odpírají. ...[tato sekta] ničí obrazy Krista a svatých, popírá očistec, tvrdí, že prosby světců, s Kristem již vládnoucích, nejsou smrtelníkům nic platny.“ Augustin KADLEC, List Eneáše Silvia o cestě na snèm do Benešova a o dvojí zastávce v Táboře, Jihočeský sborník historický 22, 1953, s. 107-112, 133-148, zde s. 107-108.

${ }^{6}$ Kořeny zobrazení anděla s kalichem nalézáme v eucharisticky orientované ikonografii Ukřižování z předhusitské doby. Jako samostatný motiv je známe $\mathrm{z}$ utrakvistických kachlů z druhé poloviny 15 . století, tedy přibližně současné s táborským obrazem. Nevyřešenou otázkou zatím zůstává, zda byl kalich zpočátku umistován do středu utrakvistických oltářủ se svatostánkem a anděly, jež byly ve městech zřejmě rozší̌eny (viz dále). 
dí 15. a 16. století obvykle vyskytují obrazy související s městskou reprezentací, především městský erb, memoriální nápisy a motivy náboženského obsahu. ${ }^{7} \mathrm{~V}$ popisu výzdoby brány Enea Silvio překvapivě vůbec nezmiňuje městský erb, ačkoliv udělení městských práv a znaku Táboru císařem Zikmundem v roce 1437 na jiném místě dopisu uvádí. ${ }^{8}$ To lze snad vysvětlit tím, že erb udělený Zikmundem má tradiční podobu městského znaku s věžemi a lvem a na husitskou minulost města - zřejmě záměrně - nijak neodkazuje. Obraz anděla $s$ kalichem na bráně sice může předcházet rok 1437, kdy byl erb městu udělen, $\mathrm{v}$ každém př́padě ale lépe vyjadroval sebeurčení táborů jako komunity pod obojí, a byl zde tedy zrèmě umístěn $s$ tímto cílem.

Při celkem obvyklé, obecně křestanské kompozici anděla s kalichem je poměrně logické, že Enea Silvio se více pozastavuje nad obrazem Jana Žižky, jehož existenci považuje za jasný doklad kultu Žižky u táborů a tím i táborského kacírství. Zdůrazňuje rozpor mezi př́slovečnou nechutí Táborských k obrazu - at už šlo o jím projektovanou nechut vycházející ze starši táborské tradice, či o skutečnou, přetrvávající nedůvěru táborských měštanů $\mathrm{k}$ obrazu $^{9}$ - a tímto obrazem proklamativně vyvedeným na tak vizuálně exponovaném místě. Enea tak identifikační a memoriální roviny významu obrazu opomíjí, a naopak podsouvá táborům uctívání obrazu Jana Žižky, aby poukázal na jejich vlastní věrolomnost (obrazy ničí a proklínají, i Kristu obrazy odpírají, ale tento obraz uctívají), a tím podtrhnul jejich kacířství, k čemuž ostatně směruje celý jeho dopis. ${ }^{10}$

\footnotetext{
${ }^{7}$ Zikmund WinTER, Zlatá doba mëst českých, Praha 1991, s. 29.

${ }^{8}$ A. KaDLec, List Eneáse Silvia, s. 108.

${ }^{9}$ Enea Silvio na jiném místě dopisu zmiňuje měštana, který „tajně“ schovává u sebe obraz Panny Marie a Krista, doma jej uctívá, ale veřejně se $\mathrm{k}$ úctě nehlásí. Tamtéž, s. 109.

${ }^{10}$ Tamtéź, s. 108.
}

V komplikované společenské a náboženské situaci pozdního středověku a raného novověku v Čechách mohly městské komunity využívat symbolické obrazy, jako je kalich, k vyjádření konfesního sebeurčeni. ${ }^{11}$ Užití (případně potlačení) vizuálních prvků v hierarchizovaném organismu urbánního prostoru odráži specifické lokální mocenské poměry a meze vlivu komunit či vrchnosti, jež $\mathrm{v}$ různých úrovních usilují o demonstraci převahy ve věcech politicko-náboženských. ${ }^{12}$ Pro česká města v 16. století tak mimo Burkartovy teze o symbolické obrazové topografii ${ }^{13}$ může být inspirativní i koncept contested territories (soupeření či vymezování si teritorií pomocí konfesní obrazové komunikace) Josepha Leo Koernera, ${ }^{14}$ přičemž nemusí jít o ovládnutí prostoru komunitou pouze v konfesním smyslu, ale i kulturním, sociálním a politickém. Do jaké míry lze však tento pohled na architekturou, obrazy a symboly strukturovaný urbánní prostor uplatnit i pro 15. století, zůstává zatím bez jasnějších obrysů. Určité náznaky jsou jak na utrakvistické straně (viz výše uvedený kalich na bráně Tábora, obraz spřežení táhnoucího vůz na obě strany na domě Vaňka Valečovského a na

$11 \mathrm{~K}$ vizuální komunikaci v urbánním prostoru pozdně středověkých měst Lucas Burkart, Die Stadt der Bilder. Familiale und kommunale Bildinvestition im spätmittelalterlichen Verona, München 2000. Šíreji k české problematice Kateřina HorníčKová, Beyond the Chalice: Monuments manifesting Utraquist religious identity in the Bobemian urban context in the fifteenth and early sixteenth centuries, European Review of History. Revue européenne d'histoire 20, 2013, s. $137-152$.

12 Omezení se mohou týkat věži či vlastního umístění kostelů náboženských minorit $\mathrm{v}$ rámci topografie města nebo umístění erbů vrchnosti či provedení výzdoby k určitým ceremoniím. Tyto lokální konfesně vymezené konflikty jsou v současnosti předmětem studií čerpajících z konceptu konfesionalizace, např. Josef HrdLIČKA, Vira a moc. Politika, komunikace a protireformace v predmoderním městě (Jindřichưv Hradec 1590-1630), České Budějovice 2013, např. s. 200.

13 L. Burkart, Die Stadt, s. 20-22, 32, 331-332.

${ }^{14}$ Joseph Leo Koerner, The Reformation of the Image, Chicago 2004, s. 56-57. 
faře u sv. Jindřicha v Praze, ${ }^{15}$ vyobrazení sv. Václava, kalicha a husitské písně na pavéze horníků a hašplíru z Kutné Hory, ${ }^{16}$ městské domovní znamení $\mathrm{z}$ Prahy ${ }^{17}$ ), tak na katolické straně, např. ve vizuálních ohlasech kapistránské misie. ${ }^{18} \mathrm{Z}$ písemných zmínek i náhodně dochovaných památek je ale zřejmé, že kalich zdobil vizuálně exponovaná místa utrakvistických měst poměrně často. ${ }^{19} \mathrm{~V}$ exteriéru byl kalich umistován na městských erbech (Kutná Hora, Tábor - nejstarší pečet, Volyně, Choceň), branách (Tábor, Kutná Hora, Hradec Králové, Mladá Boleslav, Louny), domech (Praha - domov-

\footnotetext{
15 Uméní české reformace (1380-1620), edd. Kateřina HorNíčKovÁ - Michal ŠroNĚK, Praha 2010, s. 188, kat. č. VI/1 (Robert Novotný - Michal Šroněk, Mikuláš Klaudyán: Jednolist s mapou Čech).

16 Tamtéž, s. 204, kat. č. VI/9 (Milena Bartlová, Pavéza města Kutné Hory se sv. Václavem).

17 Tamtéž, s. 121, kat. č. V/12 (Dana Stehlíková, Deska s kalichem ve svatozáři), asi druhá polovina 15. století. Svatozár dokládá utrakvistický původ. Fasádu táborského domu č. p. 16 na Žižkově náměstí z první čtvrtiny 16. století, která byla $\mathrm{v}$ padesátých letech zcela přerestaurována a nebyla řádně zdokumentována, z tohoto souboru vyjímám, nebot se mi žádné spolehlivé doklady původní výmalby nepodařilo nalézt.

18 Jan Chlíbec, The Contest between the Utraquist Chalice and the Bernardino Sun, Umění 61, 2013, s. 494-519, zde s. 509-510 (bez uvedení příkladů kalicha či kritičtějšího přístupu $\mathrm{k}$ písemným pramenům - nap̌r. u Stromu hříchu u Eschenloera nemáme věrohodné doklady jeho použití ve veřejném urbánním prostoru). Se závěry autora lze souhlasit, i když autorovo tvrzení, že se tehdy rozvinula „pravá obrazová bitva mezi utrakvisty - zastánci kalicha a mezi františkány observanty a jejich ochránci“ považuji za poněkud přehnané. Není ovšem pochyb o tom, že prostředky obrazové agitace byly používány na obou stranách. Nově a inspirativně ke kapistránské symbolice Antonín Kalous, Between Hussitism and Reformation, 1450s-1520s, in: The Transformation of Confessional Cultures in a Central European City: Olomouc, 1400-1750, ed. Antonín Kalous, Roma 2015, s. 41-64.

19 K. HorníČKovÁ, Beyond the Chalice, s. 139-140, 142-143. Výčet není úplný a odráží úroveň znalostí pramenů o jednotlivých městech. Souborná studie na toto téma nebyla - pokud vím - zpracována.
}

ní znamení kalicha ve svatozáři, Tábor č. p. 6), městských stavbách (Hradec Králové - kašna), průčelích a věžích kostelů (Staré Město pražské: kostel Panny Marie před Týnem, Nové Město pražské: kaple Božího těla, Kutná Hora: sv. Barbora, Louny: sv. Mikuláš, Hradec Králové: sv. Antonín), v interiérech zejména na vybavení kostelů, křtitelnicích (Tábor), nástěnných malbách (Kutná Hora: sv. Jakub, Velké Meziříčí: sv. Mikuláš, Slaný: sv. Gothard) a na radnicích, pečetích a pečetidlech. ${ }^{20} \mathrm{Z}$ písemných pramenů máme i doklad o užití motivu Krista s kalichem na raných utrakvistických oltáríich. ${ }^{21}$ Uvědomíme-li si však demonstrativní charakter takových památek, není v tomto smyslu překvapivé, že dochovaných veřejných zobrazení kalicha $\mathrm{v}$ městském prostředí je minimum.

V 16. století se města konfesně a etnicky dále štěpí, přičemž ve správě kostelního majetku hrají stále větší roli laikové (zástupci městké komunity a lokálních elit), at̉ už jde o město královské, nebo poddanské, katolické, utrakvistické, nebo smíšené. Na prríkladu jižních Čech lze ukázat, že doba je charakterizována přetahováním se o kněze, secesionistickými snahami z majoritních farností do zabraných filiálních kostelů (např. opuštěných klášterních: České Budějovice, Jindřichův Hradec) či kostelů nově postave-

${ }^{20}$ Zuzana Vక̌ETEČKOVÁ, Iconography of the Mural Paintings in St. James's Church of Kutná Hora, in: The Bohemian Reformation and Religious Practice 3, edd. Zdeněk V. David - David R. Holeton, Praha 2000, s. 127-146; Rudolf TeCL, Tábor v drubé poloviné 15. století, Husitský Tábor 2, 1979, s. 87-89; Umèní české reformace, s. 204, kat. č. VI/9 (M. Bartlová, Pavéza města Kutné Hory); tamtéž, s. 198, kat. č. VI/6 (K. Horničková, Radní deska s městským erbem Kutné Hory), tamtéž, s. 200, kat. č. VI/7 (V. Vaněk, Utrakvistická pečet města Kutné Hory).

${ }^{21}$ Roku 1434 odkaz Beneše od brány Strahovské na oltář s Kristem na kř́ži a kalichem $\mathrm{s}$ hostii smočenou v krvi proudící z jeho boku. Václav Vladivoj ТомЕк, Základy starébo mistopisu pražskébo, III. Malá Strana, Praha 1872, s. 1. Kalich mohl být na utrakvistických oltárích umistěn rovněž jako atribut Husův. 
ných (Písek, Jindřichův Hradec). Obrazovou kulturu poddanských měst navíc ovlivňují politické a konfesní konflikty mezi vrchností a městskou komunitou, které nezř́dka pramenily z odlišné konfesní orientace (Jindřichův Hradec, Velké Meziříčí, Dačice). V oblasti uměleckého patronátu se příslušníci lokálních městských elit snaží reprezentovat stále více sebe sama než jednotu komunity. Městské nekatolické komunity využívají stavebních památek a určitých obrazových kompozic ${ }^{22} \mathrm{v}$ rámci konfesních identifikačních strategií uvnitř města ${ }^{23}$ - vzniká tak jakási symbolická topografie města, definovaná konfesně-politicky a prezentovaná skrze vizuální prostřed$\mathrm{ky}^{24} \mathrm{~V}$ ní se uplatňují i další kompozice s kalichem, např. obraz husy s kalichem vedle „kalvínských veršü“ uvádějí účty rekatolizátora v Novém Bydžově. ${ }^{25}$ Jak už bylo řečeno, k oživení role obrazů v konfesní polemice dochází i na katolické straně.

Nejznámější dochovaný symbolický obraz kalicha z 15 . století se nachází v kostele sv. Jakuba v Kutné Hoře nad později vestavěnou klenbou kaple kutnohorských mincírů a pregéřů, jež jej ochránila před zamalováním či poškozením v rekatolizační době. Jednotlivé malby svým christologickým a eucharistickým zaměrením (Bolestný Kristus ve svatostánku, Ukřižování, Madona s děckem poukazující na inkarnaci Krista) i jednoduchým, ikonickým

${ }^{22}$ Témata jako je podávání z kalicha v utrakvistických graduálech, luteránské téma Zákona a milosti (České Budějovice), postavy Luthera či Husa (Jindřichův Hradec, Krupka, Kutná Hora), ale také texty dle luteránských a bratrských předloh (Slavonice, Mladá Boleslav, Nový Bydžov).

${ }^{23} \mathrm{~K}$ tomuto kriticky např. Ondřej JAKUBEC a kol., Ku vě̌né památce. Malované renesančni epitafy v českých zemích, Olomouc 2007.

${ }^{24}$ Konfesně vymezená lokální centra v rámci jednoho města lze např́iklad pozorovat $\mathrm{v}$ Dačicích a Slavonicích. Tato strategie symbolické topografie bude ostatně skvěle použita $\mathrm{v} 17$. století protireformací, např. při zakládání klášterů v prostředí původně nekatolických měst.

${ }^{25}$ Kateřina Horní̌̌KOVÁ - Michal ŠRONĚK, The Bydžov Altarpiece and Its Denominational Transformations, Umění 69, 2012, s. 363-383, zde s. 383, pozn. 88. provedením odpovídají ideálu utrakvistické tvorby, jak byla definována v Artikulech na držení kompaktát roku 1437. Chronologie maleb není přesně stanovena, víme jen, že malby vznikly jistě před rokem 1486. Zuzana Všetečková je datuje do doby po roce 1446 či obecně do čtyřicátých až šedesátých let 15 . století, s datací do doby po roce 1450 se ztotožňuje i Aleš Mudra. ${ }^{26}$ Nad obrazem Ukřižování je obraz gotického kalicha s hostií a nápisem „weritas wincit“, husitským sloganem inspirovaným Třetí knihou Esdrášovou $(3,12)$ a jedním z Husových listů z června $1413 .{ }^{27}$ Kompozice ukazuje kalich už jako etablovaný symbol sub utraque, jak o jeho užití víme už ze standarty poselství do Basileje v roce 1432, kde je symbol kalicha s hostií také kombinován s Ukřižováním. ${ }^{28}$ Spojení obou obrazů představuje husitskou obdobu pozdějších německých didakticko-katechetických obrazů pro lidového diváka, jež Bob Scribner označuje pojmem minimale Bildlebre. ${ }^{29}$ Zřejmě bylo toto spojení $\mathrm{v}$ rané fázi utrakvistického umění velmi oblíbené, obdobně jako kompozice Bolestného Krista s kalichem a hostii, který byl v kostele sv. Jakuba vyobrazen hned vedle kalicha. Celkově toto spojení odkazuje na primární kultovně-eucharistický

${ }_{26}$ Z. VŠETEČKOVÁ, Iconography of the Mural Paintings, s. 127-146; TÁž, Stredovéká násténná malba ve středních Čechách, Praha 2011, s. 180-181, 183. Aleš MudRA, Ecce panis angelorum. Výtvarné uméni pozdního středovéku v kontextu eucharistické devoce v Kutné Hoře (kolem 1300-1620), České Budějovice - Praha 2012, s. 185. ${ }^{27}$ M. Jana Husi Korespondence a dokumenty, ed. Václav NovotnÝ, Praha 1920 (= Sbírka pramenů českého hnutí náboženského 14, Spisy M. Jana Husi 9), s. 170 , č. 63 .

${ }^{28}$ Utrakvistická delegace do Basileje v roce 1432 vztyčila před vstupem do Norimberku standartu s kalichem a hostií a nápisem Veritas omnia vincit na jedné a Ukřižováním na druhé straně. Že obraz byl chápán jako obrazové konfesní poselství, dokládá fakt, že tento akt vyvolal značné rozhořčení mezi přihlížejícími.

${ }_{29}$ Bob SCRIBNER, Das Visuelle in der Volksfrömmigkeit, in: Bilder und Bildersturm in Spätmittelalter und der frühen Neuzeit, ed. Bob Scribner, Wiesbaden 1990 (= Wolfenbütteler Forschungen 46), s. 9-20, zde s. 11. 
a eschatologický rozměr malírského programu. ${ }^{30}$ Proklamativní užití symbolu kalicha na standartě poselství do Basileje však naznačuje i možné další konotace kompozice s kalichem v interiéru kostela sv. Jakuba, které souvisely s identifikací farní městské komunity s utrakvismem skrze symbol. Chrámový prostor středověkého městského kostela funguje jako semi-veřejný urbánní prostor, ${ }^{31}$ tím lze chápat nápis a kalich ve sv. Jakubu jako poukaz na prijímání pod obojí nejen na teologické rovině, ale i na rovině společenské, jako symbol stmelující lokální farní komunitu.

S politickou konsolidací oficiálního dvojvěří po roce 1485 je kalich vnímán stále více jako politický symbol, čímž ovšem není oslaben jeho teologický a identifikační rozměr. Dokladem toho je např. reprezentativní dekorativní pavéza z Kutné Hory, kde je kalich umístěn demonstrativně nad postavou sv. Václava; celek byl lemován textem husitské písně. ${ }^{32}$ Pokud skutečně byla umístěna na kutnohorské radnici, jak si myslí Milena Bartlová, tak ji lze číst jako doklad identifikace městské komunity (v zastoupení jejích elit) jednak s českou náboženskou tradicí ztělesněnou sv. Václavem $\mathrm{v}$ podobě, jak byla reinterpretována utrakvismem, a jednak s odkazem husitské minulosti. Podobně odkazem na husitskou minulost konstruují vlastní obraz i táborské elity už ve zmíněných dvou štítech nad vnější branou Tábora a posléze při zakázce na nový městský znak, pravděpodobně též pro radnici, v letech 1515-1516.

Existují však náznaky, že s rozmachem nových reformačních směrů v první třetině 16 . století teologická (eucharistická) rovina symbolu znovu nabírá na dủležitosti. Svoji roli zde - dle mého názoru - hraje narůstající konfesní roztříštěnost a v užším smyslu

${ }^{30}$ A. Mudra, Ecce panis angelorum, s. 185-187.

${ }^{31}$ S. RAU - G. Schwerhoff, Öffentliche Räume in der früben Neuzeit, s. 34-36.

32 Umění české reformace, s. 204, kat. č. VI/9 (M. Bartlová, Pavéza města Kutné Hory). Pavézu Bartlová spojuje př́mo s Kutnohorským smírem roku 1485. zejména konkrétně odmítnutí remanenční teorie Jednoty bratrské utrakvisty. Př́íladem takového aktuálního vnímání kalicha, který zároveň skrze postavu sv. Vojtěcha vizuálně odkazuje na starou tradici české církve, na kterou utrakvismus navázal, je deska z oltáře z Vliněvsi se sv. Vojtěchem a Janem Husem, kde kalich s krví, který sv. Vojtěch drží, koresponduje s plasticky znázorněným, „živým“ Ukřižovaným Kristem na dorsálním kříži kasule. ${ }^{33}$ Ikonografie kompozice vyjadřuje utrakvistické přihlášení se (skrze postavu Husa) k transsubstanciační teologii oproti názoru Jednoty. Zdá se, že právě teologická rovina symbolu hrála roli v aktualizaci eucharistických témat, které měly vyjádřit svébytnost utrakvismu.

S vnitřním vývojem utrakvismu a s jeho vymezováním se vůči náboženským konkurentům, Jednotě bratrské a posléze luterství, žejmě souvisí obliba pozdně gotických oltářů s tabernáklem mezi anděly. ${ }^{34}$ Pokud lze při zlomkovitém dochování vủbec zobecňovat, stoupá obliba těchto oltářů ve dvou vlnách: na přelomu 15 . a 16. století a potom kolem roku 1530. Nápadné je, že všechny tyto oltáře se dochovaly s upraveným středem, př́padně úplně ve zlomcích. Tudíž na otázku, zda v centru oltáŕe nemohl být původně zobrazen kalich, nemůžeme uspokojivě odpovědět a je pravděpodobné, že ani v budoucnu to nebude pro stav dochování možné. I když nejde o převratné inovace (spojení motivu kalicha a anděla vychází z běžné ikonografie Ukřižování, letící andělé zase z ikonografie výzdoby gotických svatostánků) a dekorace kamnového kachle z výzkumů hradu Sionu dokládá znalost kompozice

33 Uméní české reformace, s. 142-144, kat. č. V/19 (K. Horníčková, Deska z oltáře z Vliněvsi se sv. Vojtěchem a Janem Husem).

${ }^{34}$ Dochovalo se jich ve zlomcích asi deset. Základní shrnutí poznatků viz Kateřina HoRníčKOvÁ, Utrakvistický krídlový oltár se svatostánkem mezi andély a jeho geneze, in: Středověký kaleidoskop pro muže s hůlkou. Věnováno Františku Šmahelovi k životnímu jubileu, edd. Eva Doležalová - Petr Sommer, Praha 2016, s. 314-322. 
$\mathrm{s}$ kalichem mezi anděly pro druhou čtvrtinu 15 . století, ${ }^{35} \mathrm{v}$ oltář́ch toto spojení v 15. století doložit nemůžeme. ${ }^{36} \mathrm{Od} 16$. století byl do centra tabernáklu, prrípadně na predelu oltáře ${ }^{37}$ malován spíše obraz Krista Bolestného, někdy ovšem i s kalichem. Pro užití motivu kalicha mezi anděly i na oltáŕi však mluví jeden málo známý př́klad ze 16. století: motiv kalicha mezi anděly je dochován na rohenickém oltári, datovaném rokem 1533 a dnes značně

\footnotetext{
${ }^{35}$ Umèní čské reformace, s. 118, kat. č. V/10 (V. Brych, Kachel s kalichem neseným anděly a s erbem Jana Roháče z Dubé), nalezeno při výzkumu E. Janské na hradě Sionu, dat. (1420)1426-1437. Další literatura ke kachlím $s$ anděly a kalichem: Zdeněk HazLBAUER, Krása středovékých kamen, Praha 1998; Jiř́ FRÖHLICH - Vlastimil SiMOTA, Dvé jibočeská gotická kamnová akroteria s vyobrazením kalicha, Muzejní a vlastivědná práce. Časopis Společnosti prátel starožitností 43 (113), 2005, s. 221-224. Kachle s kalichem neseným anděly: Jan Frolík, Kacble Chrudimska, Chrudim 2003, č. 68, 70; Vladimír Brych, Kacble doby gotické, renesanční a barokní. Výběrový katalog Národníbo muzea v Praze, Praha 2004, kat. č. 230; Rudolf Krajic, Strédovéká kacblová kamna v Táboře (Arcbeologický výzkum v Kŕźžkové ulici, čp. 28), Tábor 1997, s. 65-67.

${ }^{36}$ Argumentaci shrnula K. HORNiČKOVÁ, Utrakvistický kr̆́ílový oltár̆, s. 318, a TÁž, Oltár z kostela sv. Kateřiny v Chrudimi a utrakvistické oltáre se svatostán$\mathrm{kem}$, in: Gotické a raně renesanční umění ve východních Čechách. Příspěvky vědecké konference, edd. Ivo Hlobil - Milan Dospěl, Hradec Králové 2014, e-kniha, <http://www.udu.cas.cz/data/user/docs/gotika_VC_0601_celek.pdf, s. $132-143$, zde s. 140-142. Z oltárů $s$ anděly ve středu z 15 . století máme dochován pouze jeden, oltár ze Slavětína, z doby kolem poloviny 15. století, ré byl stred (misto eucharistické kompozice? - jsou zde zbytky černé malby rámování snad svatostánku) cíleně poškozen (dosud jsou znát zářezy, zřejmě po kopí). $S$ tabernáklem ve středu, ale bez andělů je zobrazen oltár ve Franusově graduálu z Hradce Králové z roku 1505, tabernákl zde ale obsahuje monstranci, nikoli kalich. Není bez zajímavosti, že pozdějš́i iluminace představujici interiér téhož kostela uvádí deskový oltár s anděly, tabernáklem a Kristem Bolestným uprostřed (nikoliv monstranci).

${ }^{37}$ Např. predela Oltáře Nanebevzetí Panny Marie z kostela Panny Marie na Náměti v Kutné Hoře od Mistra Michala z Prahy, kol. 1520. Kateřina HorNíČKOVÁ, Město jako komunikační prostor. Utrakvismus, obrazy a reprezentace, in:
Umění české reformace, s. 178 .
}

poškozeném. ${ }^{38}$ Oltář pochází z kostela sv. Jana Křtitele v Rohenicích u Českého Meziřićí. Celkový stylový charakter oltáře odpovídá pokročilé podunajské škole a práce se připisuje okruhu Mistra čáslavské desky.

Na středové desce oltář nese klasickou utrakvistickou kompozici stojících andělů držících svatostánek s dodatečně vloženou deskou s Kristem Bolestným s kalichem. Původní uspořádání středu zde, stejně jako u jiných oltářu této skupiny, není čitelné. Na silně poškozené, ale zřejmě mladší predele ${ }^{39}$ se opakuje motiv andělů, tentokrát ale adorujících kalich. Kalich zde stojí samostatně jako symbol, nikoliv jako atribut Krista Bolestného. Kompozice proti sobě otočených adorujících andělů se na oltári dubluje v akcentaci eucharistického významu. Na detailu predely je vidět, že andělé drží kartuši s namalovaným kalichem, který zdobí dviřka uprostřed predely. Prostor zřejmě sloužil pro Tělo Boží nebo pro odkládání liturgického náčiní, kalich zde tedy rovněž odkazoval na místo uchovávání jednoho či druhého. Zde se tedy symbolické zobrazení kalicha vrací ke svému eucharistickému teologickému základu z hlediska náboženské praxe, a to přímo v liturgickém kontextu nekatolické, snad utrakvistické komunity. Toto vyobrazení by snad mohlo podporovat hypotézu, kterou vyslovil již Zdeněk V. David, že kolem dvacátých let 16 . století dochází k rehabilitaci utrakvistického pojetí kalicha, která je utrakvistickou odpovědí dobové situaci - reakcí na luterství a na radikální reformaci Jednoty bratrské. ${ }^{40}$ Akcentu na tradiční chápání eucharistie v utrakvismu

${ }^{38}$ Oltár̆ rohenický, Světozor, 25. února 1891, <http://archiv.ucl.cas.cz/gettimg?path=SvetozorII/25.1891/6/71.png>; Jaroslav PEŚINA, Česká malba pozdní gotiky a renesance. Deskové malírství 1450-1550, Praha 1950, s. 93, 136, kat. č. 441446 (uvádí bez fotografie).

${ }^{39}$ Asi z druhé poloviny 16 . století (?), ale vzhledem z rozsahu poškození malby to nelze ríci s určitostí.

${ }^{40}$ Zdeněk V. DAvid, Nalezení strédní cesty. Liberální výzva utrakvistů Římu 
odpovídá i již zmíněná ,renesance‘ utrakvistických oltárư s tabernáklem kolem roku 1530.

Identifikační a teologické roviny významu se v symbolu kalicha budou však i nadále prolínat. V kontextu vyhrocující se náboženské situace $v$ Čechách je třeba číst zobrazení kalicha a připojený nápis na severní Mýtské (Mautnerské) bráně v Hradci Králové z roku 1520, jež vyjadřuje sebeidentifikaci a dominantní postavení utrakvismu ve městě a snad i odkaz na kompaktáta. ${ }^{41}$ Kalich je zde sice symbolem utrakvismu a jeho náboženské praxe, ale ve smyslu disciplinace městské komunity. Ač se může zdát, že nápis zdůrazňuje jednotu království a náboženství v Čechách, vystupuje ostře proti jakýmkoli deviacím od dvou oficiálně uznaných konfesí (katolictví a utrakvismu) a je namířen zejména proti jediné tehdejší alternativě oficiálního dvojvěří, Jednotě bratrské. Obraz kalicha se zde stává symbolickým vyjádřením identifikace komunity, hierarchie a lokálního ovládnutí prostoru. V tomto směru je ilustrativní i zmínka J. A. Komenského z Historie o protivenstvích církve české, ${ }^{42}$ kde píše o ikonoklasmu proti nekatolickým památkám v Hradci Králové, mimo jiné o zničení symbolu kalicha nad vchodem protestantského kostela sv. Antonína za hradbami města u Mýtské brány. Tamější symbol kalicha byl zamazán zřejmě hned v první vlně protireformace po ediktu Karla z Lichtenštejna (1624) a na místo dán obraz monstrance, převráceného kalicha, $\mathrm{z}$ něhož tekly splaš-

a Lutherovi, Praha 2012, s. 126, dále ve výkladu spisů Pavla Bydžovského, s. 210-214.

${ }^{41}$ Kateřina HorníčKovÁ, Mèstská architektura jako prostor vymezení identit. Studie ke konfesionalitě urbánníbo prostoru, in: In puncto religionis. Konfesní dimenze předbělohorské kultury Čech a Moravy, edd. Kateřina Horníčková - Michal Šroněk, Praha 2013, s. 189-204. Od brány vedla cesta do Slezska a též k panství Krajírů z Krajku, kde byla Jednota rozšířena.

42 Jan Amos KomenskÝ, Historia o těžkých protivenstvích, in: Dílo Jana Amose Komenského 9/I, Praha 1989, s. 401. ky, a defamativní protikalvínský nápis. Kostel zřejmě patřil nějaké odpadlé skupině nekatolických hradeckých měštanů, snad kalvinismem ovlivněným bratrům. Tady již nejde vůbec o teologický symbol, ale jasnou deklaraci politické moci a vítězství protireformace. Převrácený symbol kalicha namířený nyní z katolické strany proti lokálním přivržencům radikální reformace (kteři jinak sami $\mathrm{k}$ symbolu kalicha měli dosti ambivalentní vztah), ${ }^{43}$ resp. jejich paměti, není jen zajímavým paradoxem českých dějin, ale vypovídá o diskurzivním, jakkoli v českém prostředí omezeném potenciálu tohoto symbolu, jeho atribucích a apropriacích, které se neomezují jen na utrakvisty. ${ }^{44}$ Během 16 . a počátku 17. století zasáhnou i další reformační směry a stanou se politickým nástrojem v náboženské polemice konfesionalizace.

Jak už bylo naznačeno, symbolická komunikace v prostředí utrakvistického města v 15 . a v první polovině 16 . století si nese jisté znaky konfesní polarizace, které se naplno projeví ve vlastní ére konfesionalizace v pokročilém 16. a 17. století. V tomto období také vrcholí postupný proces vnitřní konfesního etablování se utrakvismu, a s ním vrcholí i význam kalicha jako jeho obrazového symbolu. Co se s ním děje později, nelze z omezeně dochovaného materiálu jednoznačně ríci, jelikož památky druhé poloviny 16. století a počátku 17 . století byly zřejmě ve větší míŕe zničeny v 17. a 18. století. Stávající obrazy kalicha se však, alespoň zčásti, ve

${ }^{43}$ Martin NoDL, Kalich v pamèti Jednoty bratrské, v tomto sborníku.

${ }^{44}$ Obdobně obratně využívá již roku 1589 symbolu kalicha katolický autor a jindřichohradecký farár Václav Brosius ve svém protibratrském spise Vejstraa jindřichohradecký farár Vám Čechüm i jiným pravébo náboženství milovníkuim: na s. A1b-A2a představuje Husa jako obhájce pravé víry proti remanenčnímu učení bratrů predstavuje Husa jako obhajce pravé viry protíno kalich s hostií a Jana Augusty šlapajícího po hostii a vylévajícího obsah kalicha na zem. Umèní české reformace, s. 321, kat. č. X/2 (Michal Šroněk, Václav Brosius: Koule Danielova, kterouž podává draku pikhartskému, jinak valdenskému). 
městech nějakou dobu udržely - o jejich přetrvávající vizuální prominenci svědčí i to, že $\mathrm{v}$ rekatolizačním procesu hrála eliminace těchto exponovaných obrazů kalicha důležitou symbolickou roli. ${ }^{45}$ Otázku vlivu luteranizace utrakvismu na veřejné užívání symbolu kalicha tudíž nelze přesněji zodpovědět. Mohl zde hrát roli i posun od reprezentace náboženských komunit směrem $\mathrm{k}$ reprezentaci jednotlivce a rodiny $\mathrm{v}$ individuálním eschatologickém rozměru během 16. století, v rámci kterého tradiční, v podstatě již zcela abstrahované a komunitně orientované symboly, jako byl kalich, těžko mohly plnit svoji roli. ${ }^{46}$

\section{The symbol of the chalice in the public space of Utraquist towns}

From a theological perspective, the chalice in fifteenth- and sixteenth-century Bohemian Utraquism symbolised lay communion under both kinds. With the emergence of the Utraquist urban elite in the first half of the fifteenth century, however, its representational function take on increased importance, serving to manifest the status of Utraquism as one of the legal faiths in Bohemia and a dominant denomination in a particular town. Written references along with fragments of preserved monuments reveal that the chalice as an independent motif decorated visually prominent sites in Utraquist towns in the fifteenth and early sixteenth centuries. The symbol of chalice was placed on the exteriors, including coats-of-arms, gates, houses, town buildings, and church façades, and in interiors, particularly on wall paintings and decorative furnishings of churches, town halls and houses, as well as on seals and tiled stoves. Its depiction on gates and town walls was a common expression of Utraquist identity

${ }^{45}$ M. ŠRONĚK, De sacris imaginibus, s. 61-62.

46 Tato studie vznikla v rámci grantového projektu GA ČR 14-25417S Tvář komunity. Obrazy, symboly a performance pozdně středovékébo a rané novovékébo města. Výzkum čerpal inspiraci rovněž z metodologických východisek rakouského projektu o utváření komunit rakouské vědecké grantové agentury FWF,
SFB 42 Visions of Community. both in a religious and political sense and it has been understood as such even by the Utraquists' opponents. Thus symbolic communication with images in the Utraquist towns in this period reveals a certain degree of localised religious polarisation that would increase later in the period of the Confessionalisation at the end of the sixteenth and into the seventeenth century. 